\title{
To Study the Effect of Seismic Analysis Of Hyperbolic Cooling Tower
}

\author{
Pranali M. Fulzele ${ }^{1}$, R.V.R.K Prasad ${ }^{2}$ \\ ${ }^{I}$ M-Tech student,${ }^{2}$ Associate Prof. KDK College of Engineering, Nagpur (Maharashtra) India
}

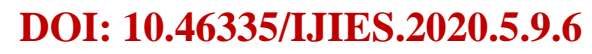

\begin{abstract}
Natural draught cooling towers are very common in modern day thermal and nuclear power stations. These towers with very small shell thickness are exceptional structures by their shear size and sensitivity to horizontal loads. The boundary conditions should be considered as been top end free and bottom end is fixed. The material properties of the cooling tower have young modulus 31GPa and Poisson Ratio 0.15. These cooling towers have been analyzed for seismic loads \& wind load using Finite Element Analysis. The seismic load will be carried out for zone 2 and zone 4 in accordance with IS: 1893 (part 1)-2002 and by modal analysis and wind loads on these cooling towers have been calculated in the form of pressures by using the design wind pressure coefficients as given in IS: 11504-1985 code along with the design wind pressures at different levels as per IS: 875 (Part 3) - 1987 code. The analysis has been carried out using Ansys 18.2. The outcome of the analysis is max deflection, \& max equivalent stress.
\end{abstract}

Keywords: Cooling tower, FEA, Seismic analysis \& wind analysis.

\section{I- INTRODUCTION}

$\mathbf{T}$ he natural draught cooling tower is a very important and essential component in the thermal and nuclear power stations. These are huge structures and also show thin shell structures. Cooling towers are subjected to its self-weight and the dynamic load such as an earthquake motion and a wind effects. In the absence of earthquake loading, wind constitutes the main loading for the design of natural draught cooling towers. A lot of research work was reported in the literature on the seismic \&wind load on cooling tower [1 to 5]. G. Murali et al., [1] Response of cooling tower to wind load. He studied the two cooling towers of $122 \mathrm{~m}$ and $200 \mathrm{~m}$ high above ground level. They calculated the values like meridional forces and bending moments. D.Makovička, Acta Polytechnica [2], Studied Response Analysis of an RC Cooling Tower under Seismic and Windstorm Effects. The calculated values of the envelopes of the displacements and the internal forces due to seismic loading states are compared with the envelopes of the loading states due to the dead, operational and live loads, wind and temperature actions. Finite element model is established; then mechanical characters of the tower under gravity, temperature load and wind loads are analyzed. A. M. El Ansary [3], Optimum shape and design of cooling tower, study is to develop a numerical tool that is capable of achieving an optimum shape And design of hyperbolic cooling towers based on coupling a non-linear finite element model developed in-house and a genetic algorithm optimization technique. R.L.Norton [4], studied the effect of asymmetric imperfection on the earth quake response of hyperbolic cooling tower. Shailesh S[5], software package utilized towards a practical application by considering problem of natural draught hyperbolic cooling towers. The main interest is to demonstrate that the column supports to the tower could be replaced by equivalent shell elements so that the software developed could easily be utilized.

\section{II- DESCRIPTION OF THE GEOMETRY OF THE TOWER:}

The total height of the tower is $200 \mathrm{~m}$. As shown in Fig. 1 , the tower has a base, throat and top radii of $136 \mathrm{~m}$, $85.27 \mathrm{~m}$ and $88.41 \mathrm{~m}$ respectively, with the throat 
located at $68 \%, 71 \%, 74 \%, 77 \%$ and $80 \%$ of total height above the base. It has a shell-wall thickness of $240 \mathrm{~mm}$. For other models the dimensions and $R C C$ shell thickness are varied with respect to reference tower.The boundary condition of the cooling tower has been top end free and bottom end is fixed

General equation of hyperbola is given by

$$
\frac{x^{2}}{a^{2}}-\frac{y^{2}}{b^{2}}=1
$$

In which $x$ is the horizontal radius at any vertical coordinate, $y$ with the origin of coordinates being defined by the centre of the tower throat, $a$ is the radius of the throat,

and $b$ is some characteristic dimension of the hyperboloid.

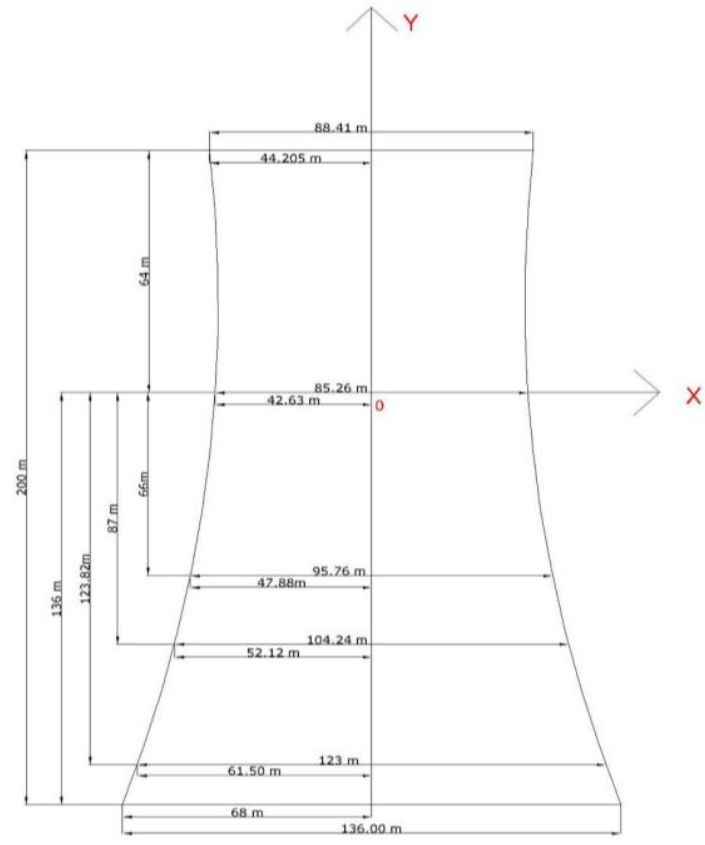

Fig. 1 -Drawing of cooling tower for $68 \%$

Table 1: Geometric details of cooling tower

\begin{tabular}{|l|c|c|c|c|c|c|}
\hline $\begin{array}{l}\text { Sr. } \\
\text { No }\end{array}$ & $\begin{array}{l}\text { Throat } \\
\text { percen-tage } \\
(\boldsymbol{\%})\end{array}$ & $\begin{array}{c}\text { Name } \\
\text { of cooling } \\
\text { tower }\end{array}$ & $\begin{array}{c}\text { Base } \\
\text { diameter } \\
(\mathbf{m})\end{array}$ & $\begin{array}{c}\text { Top } \\
\text { diameter } \\
(\mathbf{m})\end{array}$ & $\begin{array}{c}\text { Throat } \\
\text { diameter } \\
(\mathbf{m})\end{array}$ & $\begin{array}{l}\text { Throat } \\
\text { Distance } \\
\text { From base(m) }\end{array}$ \\
\hline 1 & 68 & CT 1 & 136 & 88.41 & 44.205 & 136 \\
\hline 2 & 71 & CT 2 & 136 & 88.41 & 44.205 & 142 \\
\hline 3 & 74 & CT 3 & 136 & 88.41 & 44.205 & 148 \\
\hline 4 & 77 & CT 4 & 136 & 88.41 & 44.205 & 154 \\
\hline 5 & 80 & CT 5 & 136 & 88.41 & 44.205 & 160 \\
\hline
\end{tabular}

\section{III- EARTHQUAKE FORCES}

The seismic analysis will be carried out for $1 \mathrm{~g}$ (g: Gravity acceleration $9810 \mathrm{KN} / \mathrm{m}^{2}$ ) in accordance with IS: 1893 by modal analysis of the hyperbolic cooling towers, the earthquake analysis of the shell will be carried out by response spectrum method. Earthquake analysis for the fill supporting structures (RCC frames) will be carried out by response spectrum method. For the Calculation of the Design Spectrum, the following Factors were considered as per IS 1893(Part I)-2002.

Zone factor: For Zone $\left.\begin{array}{l}\mathrm{II}=0.1 \\ \mathrm{IV}=0.24\end{array}\right\}$

as per table 2, pg16 IS 1893 (part 1):2002
Importance factor

$\mathrm{I}=1.5$, as per table 6, pg 18 IS 1893 (part 1):2002

Response reduction factor

$\mathrm{R}=3$, as per table 7, pg 23 IS 1893 (part 1):2002

\section{IV- WIND LOADS}

The wind pressure at a given height $[\mathrm{Pz}]$ will be computed as per the stipulations ofIS: 875 (part 3)-1987. For computing the design wind pressure at a given height thebasic wind speed $(\mathrm{Vb})$ will be taken as $\mathrm{Vb}=39$ $\mathrm{m} / \mathrm{s}$ at $9.2 \mathrm{~m}$ height above mean groundlevel. For computing design wind speed $(\mathrm{Vz})$ at a height $\mathrm{z}$, the risk coefficientK1=1.06 will be considered. For coefficient K2 terrain category 2 as per table 2 of IS:875 (part-3)1987 will be considered. The wind direction for design 
purpose will bethe one which world induces worst load condition. Coefficient K3 will be 1 for thetower under consideration. The wind pressure at a given height wills be computedtheoretically in accordance to the IS codal provision given as under:

$$
\begin{gathered}
\mathrm{Pz}=0.6 \mathrm{Vz} 2 \mathrm{~N} / \mathrm{m} 2 \\
\text { Where } \mathrm{Vz}=\mathrm{Vb} \times \mathrm{K} 1 \times \mathrm{K} 2 \times \mathrm{k} 3
\end{gathered}
$$

Computation of wind pressure $(\mathrm{Pz})$ along the wind direction

\section{V- FINITE ELEMENT MODELING}

Due to the complexity of the material properties, the boundary conditions and the tower structure, finite element analysis is adopted. The finite element analysis of the cooling towers has been carried out using ANSYS 18.2. The analysis has been carried out using ANSYS workbench. In the present study, only shell portion of the cooling towers have been modeled and fixity has been assumed at the base.

\section{VI- MATERIAL PROPERTIES FOR ANALYSIS OF CT}

$>$ Young modulus: $31 \mathrm{Gpa}$

$>$ Poisson Ratio: 0.15

\section{VII- TABULATION \& RESULTS}

\begin{tabular}{|l|c|}
\hline CT1 & $\begin{array}{c}\text { Location of throat at a distance of } 68 \% \text { of } \\
\text { total height of cooling tower measured } \\
\text { from base }\end{array}$ \\
\hline CT2 & $\begin{array}{c}\text { Location of throat at a distance of } 71 \% \text { of } \\
\text { total height of cooling tower measured } \\
\text { from base }\end{array}$ \\
CT3 & $\begin{array}{c}\text { Location of throat at a distance of } 74 \% \text { of } \\
\text { total height of cooling tower measured } \\
\text { from base }\end{array}$ \\
CT4 & $\begin{array}{c}\text { Location of throat at a distance of } 77 \% \text { of } \\
\text { total height of cooling tower measured } \\
\text { from base }\end{array}$ \\
\hline CT5 & $\begin{array}{c}\text { Location of throat at a distance of } 80 \% \text { of } \\
\text { total height of cooling tower measured } \\
\text { from base }\end{array}$ \\
\hline
\end{tabular}

\subsection{Static Analysis}

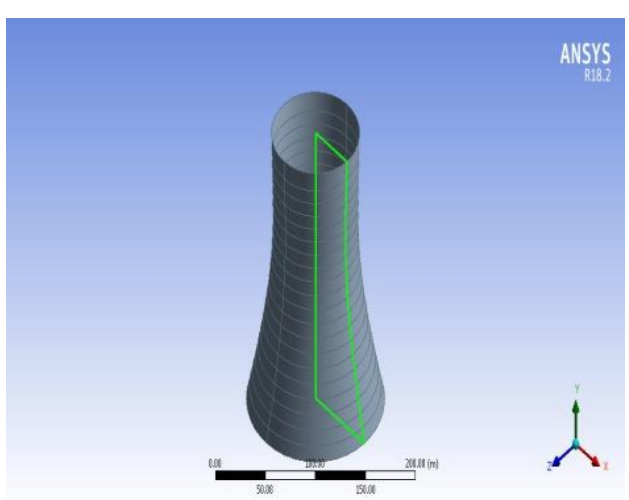

Fig: 3 Geometry

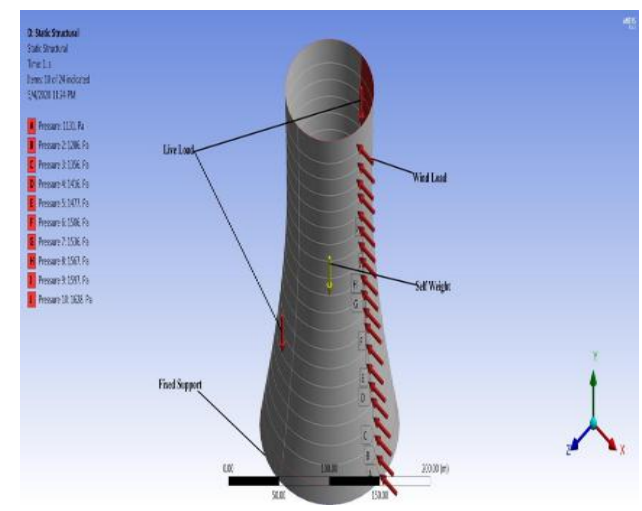

Fig: 4 Boundary condition

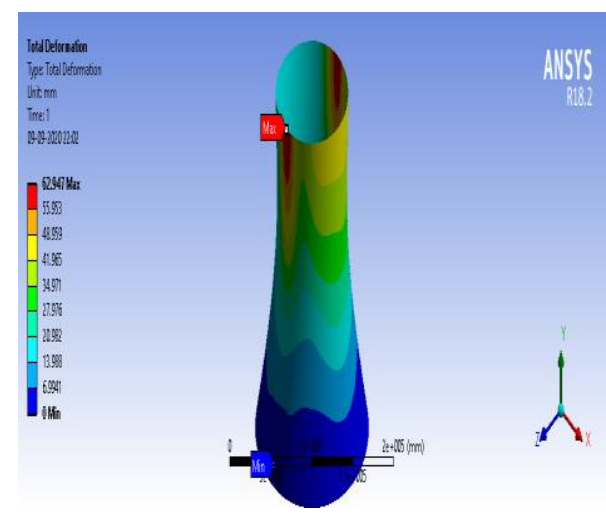

Fig: 5 Deflection in CT1

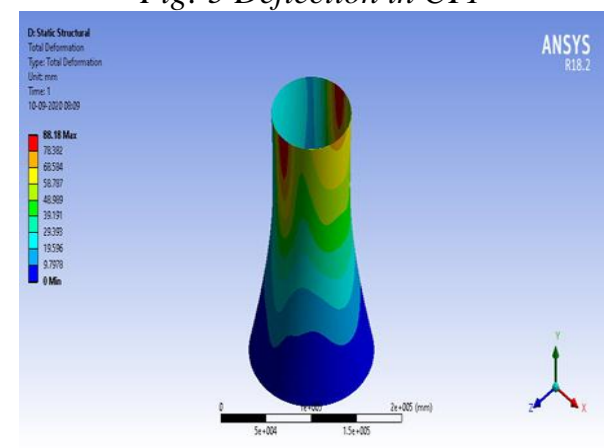

Fig: 6 Equivalent Stress in CT 1 
International Journal of Innovations in Engineering and Science, Vol 5, No.9, 2020 www.ijies.net

Table 2: Static analysis

\begin{tabular}{|c|c|c|c|c|}
\hline \multirow{2}{*}{$\begin{array}{c}\text { Type of cooling } \\
\text { tower }\end{array}$} & \multicolumn{2}{|c|}{ Total deformation (mm) } & \multicolumn{2}{c|}{ Equivalent Stress (MPa) } \\
\cline { 2 - 5 } & Zone 2 & Zone 4 & Zone 2 & Zone 4 \\
\hline CT 1 & 62.925 & 88.18 & 7.7365 & 6.0528 \\
\hline CT 2 & 56.871 & 81.053 & 5.3693 & 6.299 \\
\hline CT 3 & 53.77 & 77.537 & 5.6714 & 6.7444 \\
\hline CT 4 & 55.531 & 81.16 & 5.734 & 6.9117 \\
\hline CT 5 & 57.149 & 82.465 & 5.9152 & 7.1256 \\
\hline
\end{tabular}

7.2 Modal analysis:

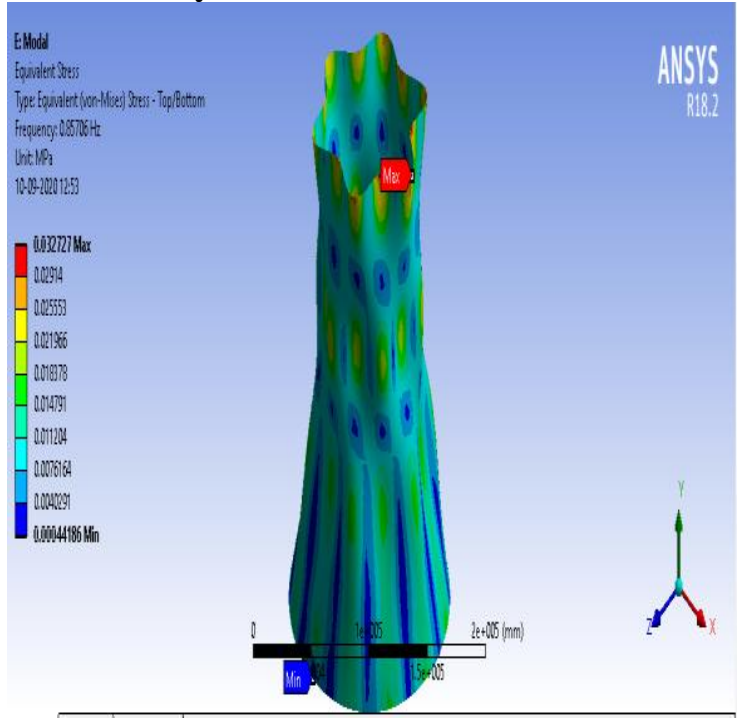

Mode $10 @$ frequency $0.85706 \mathrm{~Hz}$

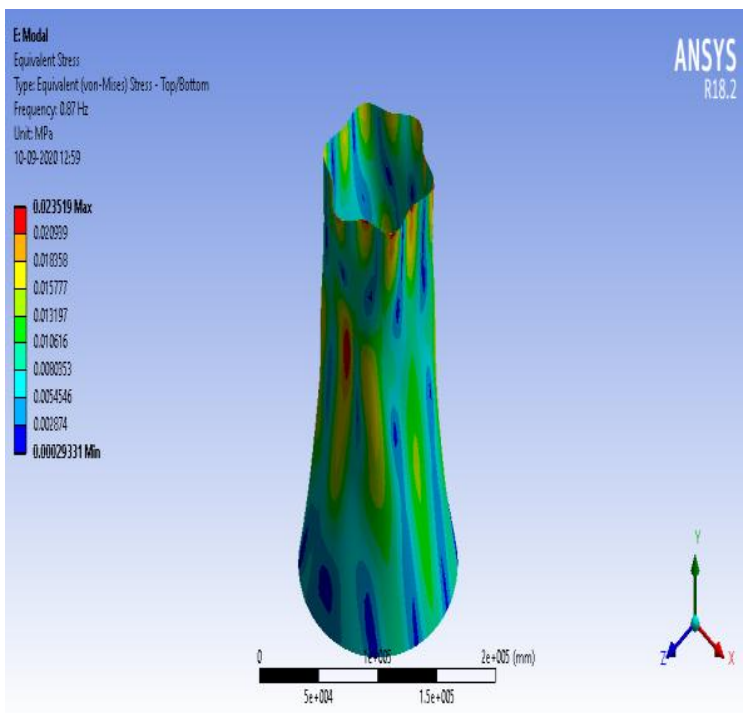

Mode $10 @$ frequency $0.87 \mathrm{~Hz}$

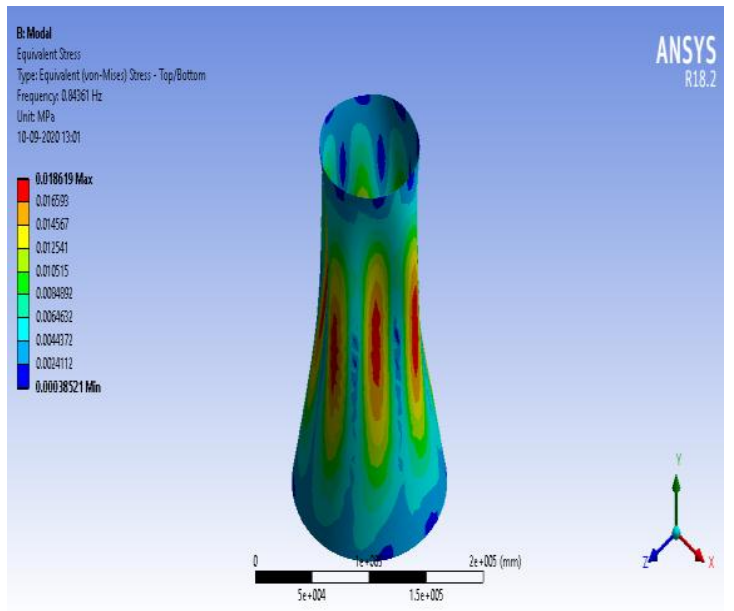

(c) Mode10@frequency $0.84361 \mathrm{~Hz}$

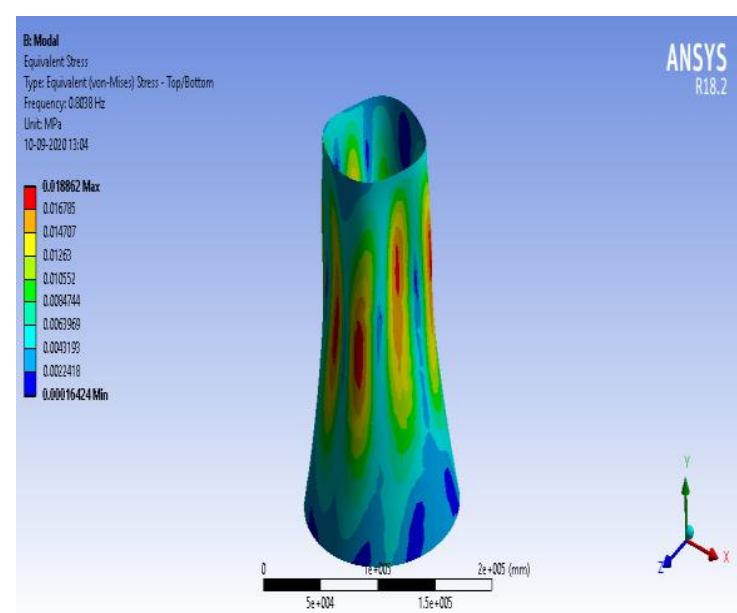

(d) Mode $10 @$ frequency $080 \mathrm{~Hz}$

Fig. 7 Equivalent stresses in modal analysis at mode 10 for zone 2 (a) CT 1(b) CT 2 (c) CT 3 (d) CT 4 
International Journal of Innovations in Engineering and Science, Vol 5, No.9, 2020

\section{$w w w . i j i e s . n e t$}

Table 3 Maximum deformation in modal analysis in Zone 2 and Zone 4

\begin{tabular}{|c|c|c|}
\hline $\begin{array}{c}\text { Location of } \\
\text { throat at from } \\
\text { bottom in } \\
\text { Percentage }\end{array}$ & \multicolumn{2}{|c|}{ Total deformation (mm) } \\
\cline { 2 - 3 } & Zone 2 & Zone 4 \\
\hline CT 1 & 0.67771 & 0.70518 \\
\hline CT 2 & 0.71217 & 0.75032 \\
\hline CT 3 & 0.75901 & 0.76851 \\
\hline CT 4 & 0.6223 & 0.63534 \\
\hline CT 5 & 0.53894 & 0.50322 \\
\hline
\end{tabular}

\subsection{Response spectrum}

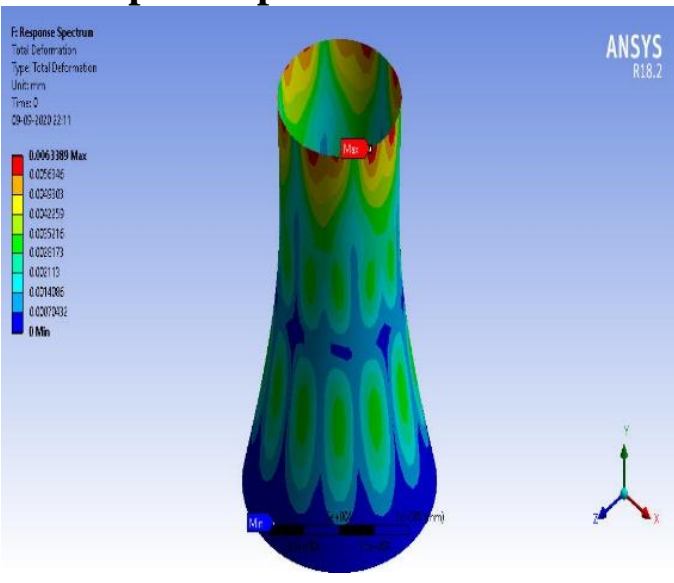

(a)

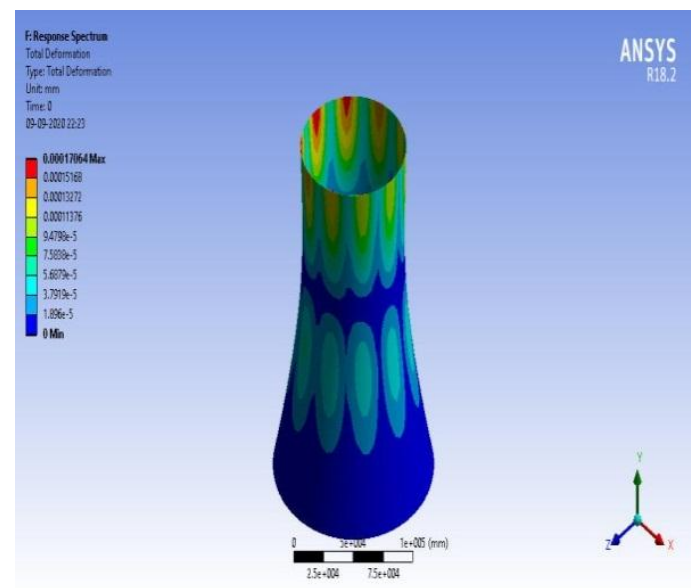

(b)

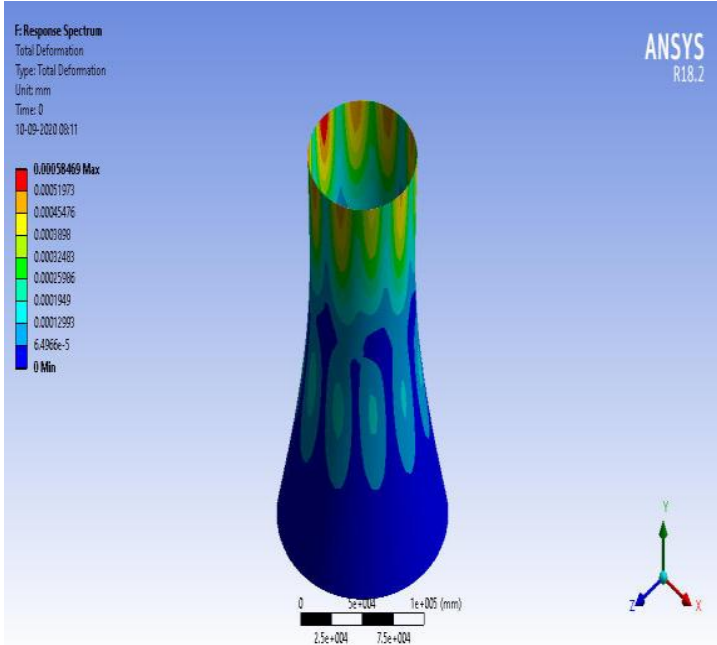

(c)

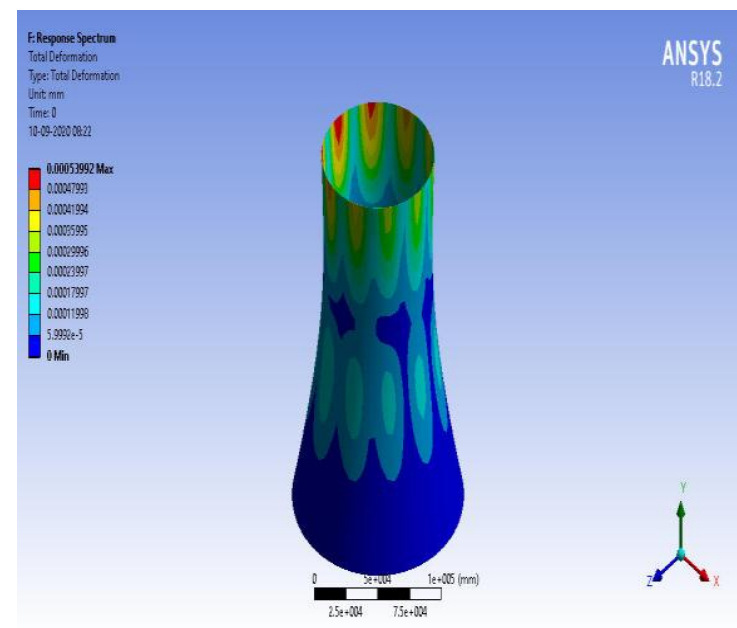

(d)

Fig 8 Total deformation in response spectrum CT 1 and CT 2 for (a), (b) Zone 2 and (c), (d) Zone 4

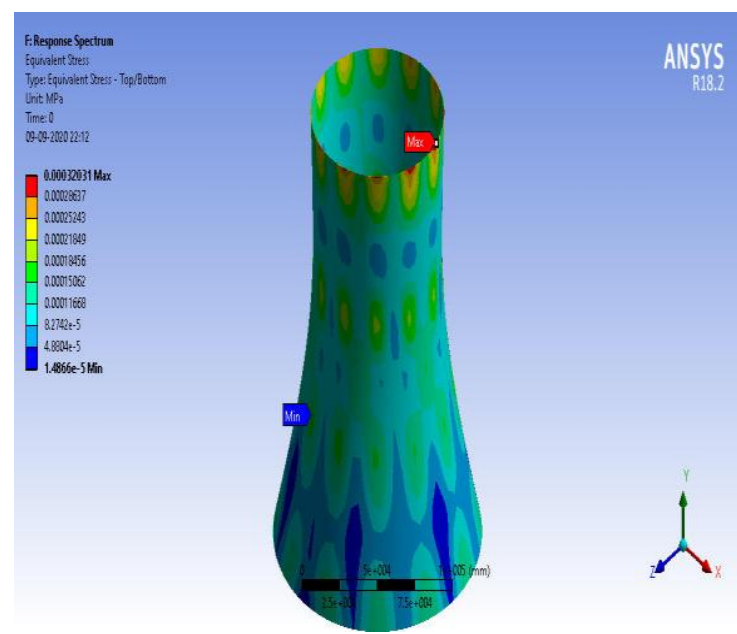

(a) 


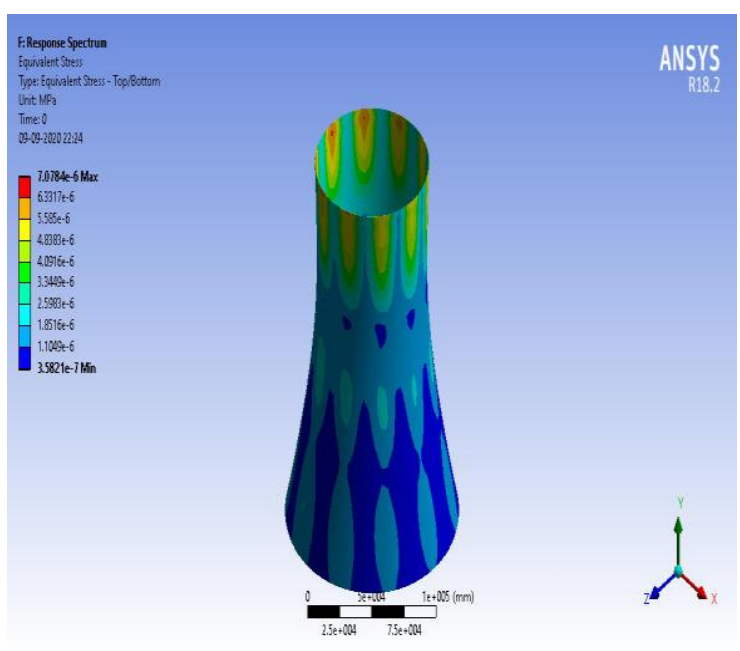

(b)

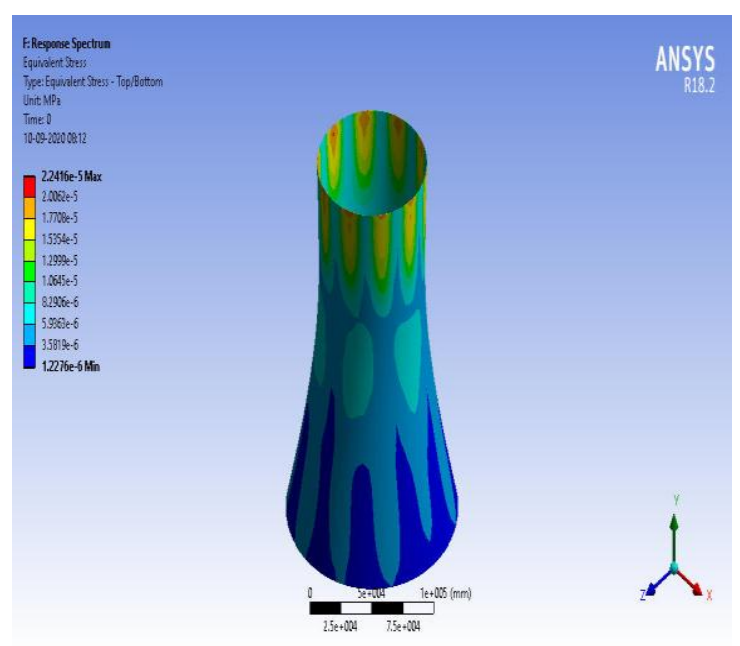

(c)

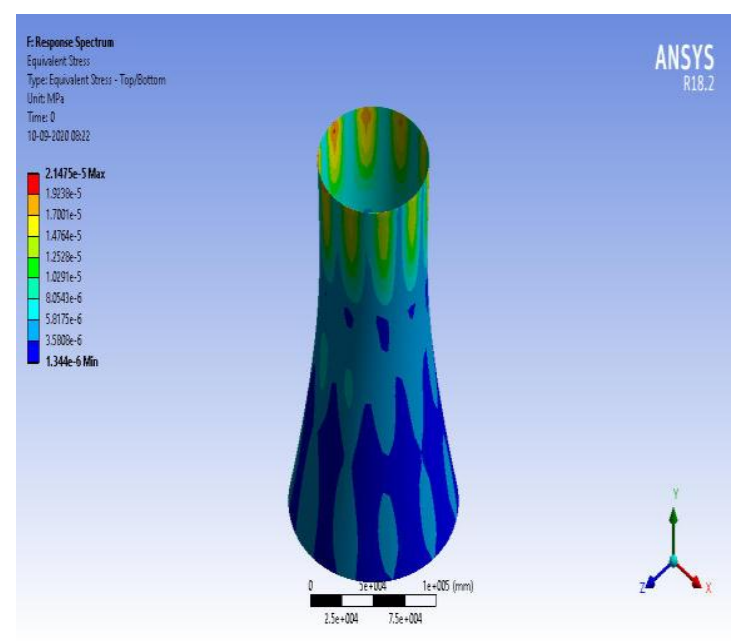

(d)

Fig 9 Equivalent stresses in response spectrum CT 1 and CT 2 for (a), (b) Zone 2 and (c), (d) Zone 4
Table 4- Response Spectrum analysis of cooling towers

\begin{tabular}{|c|l|l|l|l|}
\hline \multirow{2}{*}{$\begin{array}{c}\text { Location } \\
\text { of throat } \\
\text { at from } \\
\text { bottom } \\
\text { in } \\
\begin{array}{c}\text { Percenta } \\
\text { ge }\end{array}\end{array}$} & $\begin{array}{l}\text { Total } \\
\text { deformati } \\
\text { on (mm) }\end{array}$ & $\begin{array}{l}\text { Equivale } \\
\text { nt Stress } \\
\text { (MPa) }\end{array}$ & $\begin{array}{l}\text { Total } \\
\text { deformati } \\
\text { on (mm) }\end{array}$ & $\begin{array}{l}\text { Equivale } \\
\text { nt Stress } \\
\text { (MPa) }\end{array}$ \\
\hline CT 1 & 0.00634 & $\begin{array}{l}0.000320 \\
42\end{array}$ & 0.000585 & $\begin{array}{l}0.0000224 \\
16\end{array}$ \\
\hline CT 2 & 0.00017 & $\begin{array}{l}7.0888 \mathrm{E}- \\
06\end{array}$ & 0.000540 & $\begin{array}{l}0.0000214 \\
75\end{array}$ \\
\hline CT 3 & 0.00001 & 0.000381 & 0.029390 & 0.0011379 \\
\hline CT 4 & 0.00326 & $\begin{array}{l}0.000175 \\
94\end{array}$ & 0.023929 & $\begin{array}{l}0.0009322 \\
1\end{array}$ \\
\hline CT5 & 0.00621 & $\begin{array}{l}0.000313 \\
85\end{array}$ & 0.014909 & $\begin{array}{l}0.0007664 \\
2\end{array}$ \\
\hline
\end{tabular}

\section{VIII- CONCLUSION}

The main aim of analysis works on cooling towers as follows. In the present study FEA of 10 cooling towers viz CT1 to CT 5 has been carried out to evaluate deformation and equivalent stresses.

1. The deformation in static is least for CT 3 for zone 2 and CT 3 for Zone 4 i.e. when throat is located at $74 \%$ of total height measured from bottom.

2. The Equivalent stresses in static analysis i.e. (self-weight) are observed to be less for CT 2 for zone 2 and CT 1 for zone 4

3. In the free vibration analysis it has been observed the deformation is least for CT5 as compared to others in zone $2 \&$ CT 5 as compared to others in zone 4

4. It is evident from the seismic analysis that Equivalent stress observed to be least for CT 2 for zone 2 and CT 2 for zone 4.

5. It is evident from the seismic analysis that the deflection is the least in CT3 for zone 2 \& CT 2 for zone 4.

6. It is evident from the wind load analysis that the deformation is the least for CT 3 for zone 2 and CT 3 for zone 4

7. It is evident from the wind load analysis the Equivalentstress is for CT 2 for zone 2 and CT 1 for zone 4

\section{REFERENCES}

[1] G. Murali, C. M. Vivek Vardhan and B. V. Prasanth Kumar Reddyresponse of cooling 
towers to wind loads, arpn Journal of Engineering andApplied Sciences

[2] D. Makovička, Response Analysis of RC cooling tower under seismic and windstorm effect, Acta Polytechnica Vol. 46 No. 6/2006.

[3] A. M. El Ansary, A. A. El Damatty, and A. O. Nassef, Optimum Shape andDesign of Cooling Towers, World Academy of Science, Engineering andTechnology 602011.

[4] R.L.Norton, \& v.i Weingarten, the effect of asymmetric imperfections on the earth quake response of hyperbolic cooling towers.

[5] Shailesh S. Angalekar, Dr. A. B. Kulkarni, Analysis of natural draught hyperboliccooling tower by finite element method using equivalent plate method.

[6] IS: 11504:1985, Criteria for structural design of reinforced concrete naturaldraught cooling tower, New Delhi, India: Bureau of Indian standards.

[7] IS: 875 (Part3):1987, Code of practice for design loads (other than earthquakeloads) for buildings and structures. New Delhi, India: Bureau of Indian Standards.

[8] IS 1893 (part 1): 2002 Criteria for earthquake resistant design structure 